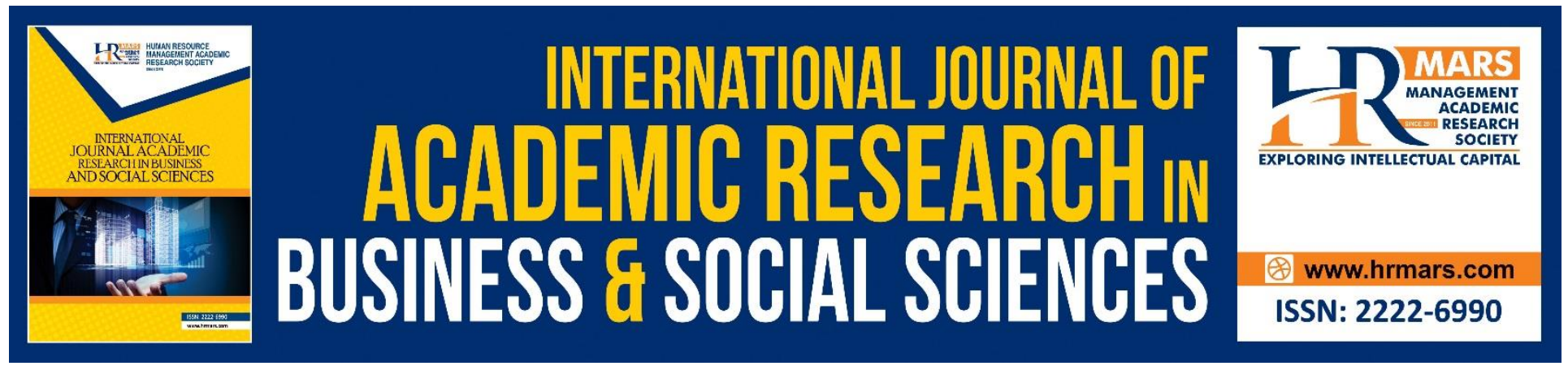

\title{
Re-Evaluation on Assumptions in Islamic Economics: A Preliminary Study
}

Mohd Zulkifli Muhammad, Mohd Syakir Mohd Rosdi, Azwan Abdullah, Nasrul Hisyam Nor Muhamad

To Link this Article: http://dx.doi.org/10.6007/IJARBSS/v8-i10/4722

DOI: $10.6007 /$ IJARBSS/v8-i10/4722

Received: 21 Sept 2018, Revised: 17 Oct 2018, Accepted: 25 Oct 2018

Published Online: 30 October 2018

In-Text Citation: (Muhammad, Rosdi, Abdullah, \& Muhamad, 2018)

To Cite this Article: Muhammad, M. Z., Rosdi, M. S. M., Abdullah, A., \& Muhamad, N. H. N. (2018). Re-Evaluation on Assumptions in Islamic Economics: A Preliminary Study. International Journal of Academic Research in Business and Social Sciences, 8(10), 162-173.

Copyright: (C) 2018 The Author(s)

Published by Human Resource Management Academic Research Society (www.hrmars.com)

This article is published under the Creative Commons Attribution (CC BY 4.0) license. Anyone may reproduce, distribute, translate and create derivative works of this article (for both commercial and non-commercial purposes), subject to full attribution to the original publication and authors. The full terms of this license may be seen

at: http://creativecommons.org/licences/by/4.0/legalcode

Vol. 8, No. 10, 2018, Pg. 162 - 173

http://hrmars.com/index.php/pages/detail/IJARBSS

JOURNAL HOMEPAGE

Full Terms \& Conditions of access and use can be found at http://hrmars.com/index.php/pages/detail/publication-ethics 


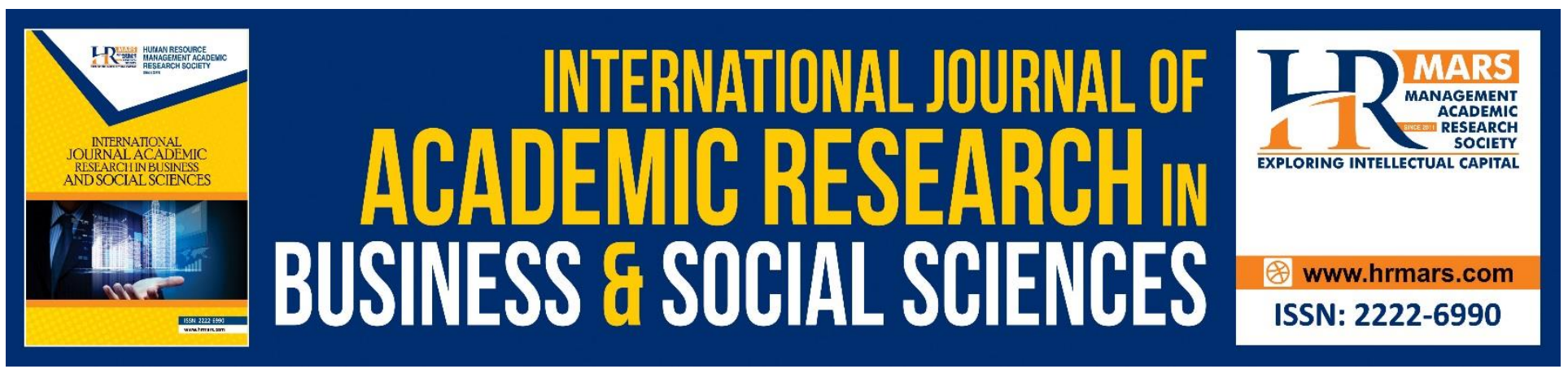

\title{
Re-Evaluation on Assumptions in Islamic Economics: A Preliminary Study
}

\author{
Mohd Zulkifli Muhammad ${ }^{1}$, Mohd Syakir Mohd Rosdi 2*, Azwan \\ Abdullah', Nasrul Hisyam Nor Muhamad ${ }^{4}$ \\ ${ }^{13}$ Faculty of Entrepreneurship and Business, Universiti Malaysia Kelantan \\ Pengkalan Chepa 16100 Kota Bharu, Kelantan, Malaysia \\ ${ }^{2 *}$ The Centre for Islamic Development Management Studies (ISDEV) \\ Universiti Sains Malaysia, Pulau Pinang \\ ${ }^{4}$ Fakulti Tamadun Islam, Universiti Teknologi Malaysia, Skudai, Johor \\ Email: ${ }^{1}$ zulkifli.m@umk.edu.my, ${ }^{2 *}$ mohdsyakirmohdrosdi@gmail.com, 3azwan.a@umk.edu.my, \\ ${ }^{4}$ nasrul@utm.my
}

\begin{abstract}
This paper is intended for a preliminary study in re-evaluating Islamic economics assumptions. The assumptions were based on the two common assumptions in economic system which includes scarcity of resources and humans unlimited wants. This paper analyses how far these assumptions in Islamic economics placed tawheed as their axis and aligned with tasawwur Islam. The analysis was done by studying opinions and views of several Islamic economists. Content analysis and literature review were utilized to reach this objective. From this preliminary study, it was found that the current assumptions in Islamic economics were not favouring towards the true concept of tawheed and tasawwur Islam. It implies the needs for a more comprehensive study to be done in order to come up with a new resolution on the real assumptions of Islamic economics.

Keywords: Re-Evaluation, Islamic Economics, Assumptions, Scarcity Of Resources, Human Unlimited Wants.

\section{Introduction}

This paper in general discusses the assumptions in Islamic economics. In specific, it intends to have an early analysis on the depth of these assumptions within the concept of tawheed and tasawwur Islam. The assumptions were divided into two which are: a) scarcity of resources, and b) human unlimited wants.
\end{abstract}

The two assumptions mentioned were actually had long been debated amongst Islamic economics experts such as Haneef (1997), Sardar (1988), Zarqa (1992), Hassan (1998), Choudhury 
INTERNATIONAL JOURNAL OF ACADEMIC RESEARCH IN BUSINESS AND SOCIAL SCIENCES Vol. 8, No. 10, Oct. 2018, E-ISSN: 2222-6990 @ 2018 HRMARS

(1999, 2011), Haider Naqvi (1983), Ragab (1995), Hasanuz Zaman (1984), As-Sadr (1987), Abusulayman (1973), Reza Nasr (1986) and other Islamic economics experts (Salleh, 2011:1-19), but there were no concrete agreement or some sort of final resolutions on the Islamic economics assumptions that truly tawheedic and aligned with tasawwur Islam and thus was left as it is (Salleh, 2011:2) ${ }^{1}$.

For the purpose of this paper which is preliminary in nature, the writer only discuss in brief supported by the Holy Quran and as-Sunnah on the opinions from several Islamic economists in relation to Islamic economics assumptions. Therefore, the analysis over the opinions was not as comprehensive as it only analyses a several few.

This paper begins with an introduction and definition of Islamic economics as how it was defined by several Islamic economists and subsequently dived into the assumptions in Islamic economics before it ends with a conclusion.

\section{Islamic Economics}

There were many variations of Islamic economics as defined by several different Islamic economists. One of them was by Akram Khan where he defined Islamic economics as a measurement of human's achievement 'falah' on their control over earth's resources and wealth through cooperation and involvement (Hassan, 1990). Mannan $(1980,1989)$ elaborated Islamic economics knowledge as social science that studies economic problems of communities upholding Islamic values. It is related to production, distribution, and consumption. Islamic economics was also defined as body of knowledge, application, and sharia law in order to prevent any forms of injustice in expending resources, for the satisfactions of human. This in turn promotes them to perform their obligations towards Allah S.W.T. and the community ( Zaman, 1984).

According to definition by Chapra (2001), Islamic economics is a branch of knowledge which helps realizing human's wellbeing through allocation and distribution of limited resources based on Islamic teachings without neglecting the individuals' freedom or affecting the balance of macro economy and ecology. Another Islamic economist, Ahmad (1992) ${ }^{2}$ defined Islamic economics as a systematic effort in order to understand economic problems and human behaviour in relation to it according to Islamic perspective.

According to Kahf (1987), Islamic economics can be seen as a branch of economic science studied based on Islamic paradigm (axiom, value system, and ethics), similar to the study on capitalist and socialist economics. Islamic economics was also seen as a derivation from the Islamic worldview

1 The debates only focus on the mechanism of Islamic economics without stressing on its philosophy and epistemology.

${ }^{2}$ Ahmad (1981) also defines Islamic economics as social discipline that reformulates economics principles within the Islamic values. 
INTERNATIONAL JOURNAL OF ACADEMIC RESEARCH IN BUSINESS AND SOCIAL SCIENCES Vol. 8, No. 10, Oct. 2018, E-ISSN: 2222-6990 @ 2018 HRMARS

which was based upon revelations and having flexible methodologies that combines western Keynesian/neoclassical economics with fiqh (Siddiqi, 1989).

While according to a definition by Haneef (1997), Islamic economics is an approach for understanding and solving human problems based upon value, norm, laws, and institutions obtained from the sources of Islamic knowledge. According to Hasan (1990), the problem solving approach must be parallel with the sharia in terms of gaining, consuming, or managing natural resources for the betterment of either for self or the others physically as well as spiritually in order to gain Allah S.W.T's blessings.

Based on the previous definitions, it was found that the study of Islamic economics focused on behavioural study of human who fully appreciate and practice Islamic values in an economic system. They would govern and manage economic resources effectively and optimally to sustain their stay in this world as a servant to their Creator based on Islamic belief (Ahmad et.al., 2011). According to Salleh (2003), human is not a creature of economy, but instead a servant to Allah S.W.T. within the context of their relationship with Allah S.W.T. (hablumminallah). While in the context of relationship between human and natural resources (hablumminannas), human is the representative or steward (khalifa) of Allah S.W.T.

\section{Assumptions In Islamic Economics}

In truth, both assumptions, scarcity of natural resources and human unlimited wants originates from common economics philosophy. They were derived from theories that was established out of PostClassical Philosophy which created the capitalist system as well as from theories from Marxist and Post-Marxist Philosophy which created socialist and communist system (Salleh, 2003). Both Capitalist and Marxist ${ }^{3}$ believed in the two assumptions mentioned.

Since the natural resources were deemed limited while human wants were deemed not, they put an effort to find an effective ways to best utilize those natural resources to fulfil their unlimited wants (Salleh, 2003; Mannan, 1989).

These assumptions were then taken up by Islamic economist later to be interpreted, assimilated, and coated with Islamic elements so that it could then be called as assumptions in Islamic economics. Amongst those Islamic economists were Kahf (1987), Siddiqi (1988), Chapra (2001), Abdul Mannan (1989), Yousri Ahmad (2002), Ahmad (1992), Khan (2002), Ahmed (2002), al-Masri (1998) ${ }^{4}$

\footnotetext{
${ }^{3}$ According to Muhammad Syukri Salleh (2003:7), both of these philosophy utilized Western Social Science approach since both were the historical residual of Western experience which began in 1945 in Western Europe post World War II. The Western nations had to come up with ways to rebuild after the destructions from the war. Hence, both of these philosophies were established.

4 According to Abdul Mannan (1989:38), transfer and exchange system in Islamic economics were driven by Islamic ethics, the power of market and non-market, whereas as transfer and exchange system in conventional economics were driven solely by the power of the market. It
} 
Here, the writer would like to convey the opinions of one of the above mentioned economist, Abdul Mannan (1989:). He believed that the basis of human's economic problems derived from the reality of which human have wants and needs that generally could not be fulfilled. However, it may be fulfilled by expending all of the man's energy resources with limited material. Adding to that, there would not be economic problems if there were unlimited resources to fulfil the various needs in economics activities. He further compared the Islamic economics activity cycle with conventional economics as per diagram below.

Based on the diagram, it can be concluded that there were no differences between Islamic economics and conventional economics besides only their nature and content.

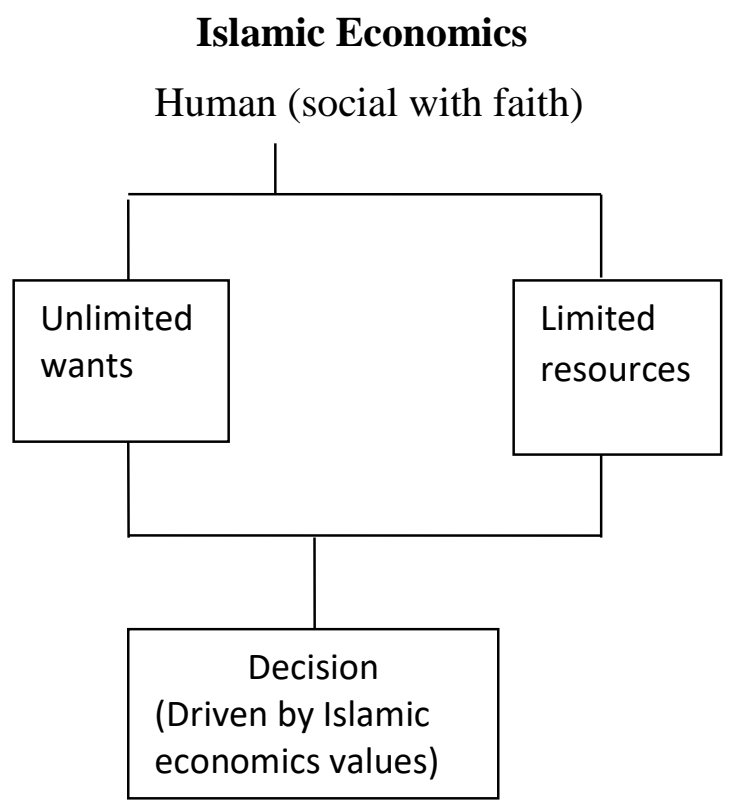

\section{Conventional Economics}

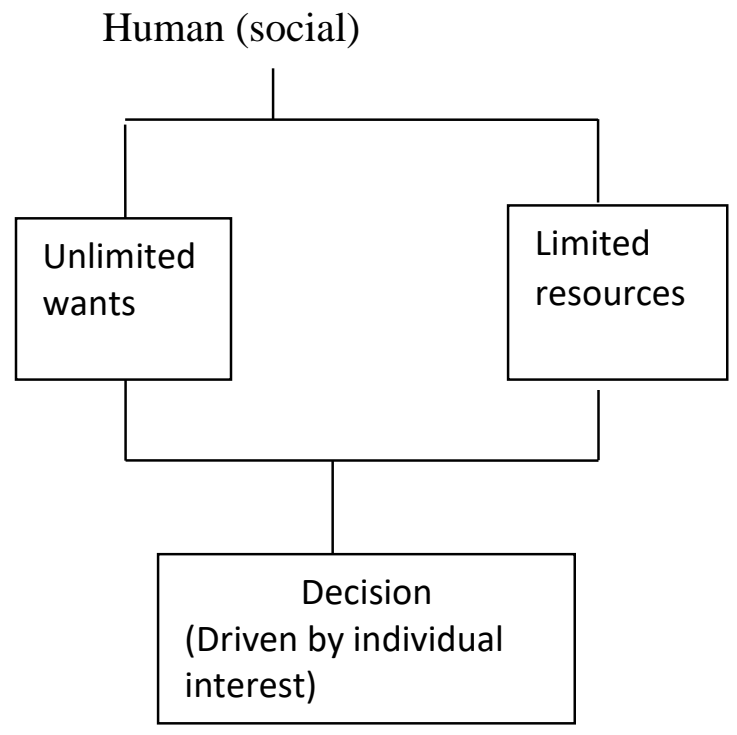

Diagram 1. Economics Activity Cycle Comparison

Questions then arise, does these Islamic economics assumptions truly follows tasawwur Islam and its philosophy or are they merely an Islamization of what was extracted from conventional economics? Or maybe it is still questionable in terms of the depth of both assumptions whether tawheed was really the pillar and axis of it and whether it is aligned with tasawwur Islam where Islamic epistemology as its absolute source?

\section{Scarcity of Resources}

Natural resources refer to the input, factor, or methods of gaining needed items or services. It can also be classified as land (nature), labour (human resources), and capital (Salvatore, 2003, Case et.al.,

showed that exchanging process in Islamic economics is more suitable with human welfare as a whole rather than only for economics welfare. 
2012, Binger \& Hoffman, 1998). Land refers to the fertility of the soil, climates, forest, and minerals. Labour meanwhile refers to all the efforts by human, be it physically or mentally that can be used to obtain the items or services required. Whereas capital is referring to the machineries, facilities, inventories, logistics, drainage, and telecommunication networks.

These natural resources were deemed limited and inadequate to fulfil human's unlimited wants. According to Ahmad et.al. (2011), if the resources are not limited, there would not be any problems in regards to economics. The problems that were raised was to show that the resources are indeed limited to be offered in order to fulfil human needs in gaining items and services required. Some of the early pioneers on this assumption in Islamic economics are Mannan (1984), Chapra (2001), Ahmed (2002, Ahmad (2004) and Khan (1994).

Take for example opinions by Khan (1994) where he believed that scarcity of resources is actually a human-made phenomena resulted by their own wastage in utilizing it or improper distribution of it. These factors are the salt to the wound but not the main causes of the scarcity of resources. This argument by Khan (1994) was also directly or indirectly supported by Zarqa (1992) and Ahmad (1992:39-40). Zarqa (1992) also believed that the resources are limited and will deplete. Therefore, what are in store on earth, no matter how big they are, they are still very well limited. Ahmad (1992:39-40) meanwhile agreed with an argument by Yousri Ahmed (2002) on the concept of relative scarcity but at the same time stated that the absolute scarcity concept should be relooked and studied (Salleh 2011).

Back to the argument by Khan (1994), this opinion was opposed by Hassan (1996). He was in the opinion that the argument by Khan (1994) was a bit confusing, similar to other economist. He argued that the Holy Quran insisted that Allah S.W.T. has complete earth and heaven with resources that are unlimited as sustenance for His creations seen and unseen includes human, animals, plants, jinn and etcetera.

Hassan (2011) argued that Khan (1994) did not realize the fact on 'existence of limitless resources for all creations at every time and places' and 'availability of resources in certain required quantities for individuals or groups at a specific time and locations' are two different things. It was not the problem of existence, but rather the availability of resources that became the main issue and concept of scarcity of resources assumptions. According to Hassan (1996), the availability of resources was in fact became the function towards knowing the existence of it, how to obtain it, utilizing it, and all the costs involved throughout the process. The Holy Quran stated that Allah S.W.T do not only grace and provide us with vast amount of resources, but tells us the fact that Allah S.W.T Himself is the source of the knowledge through kalamullah as mentioned in the Holy Quran (anNahl:89; al-A'raaf:52).

\footnotetext{
${ }^{5}$ For further details, please refer Salleh (2011:7).
} 
INTERNATIONAL JOURNAL OF ACADEMIC RESEARCH IN BUSINESS AND SOCIAL SCIENCES Vol. 8, No. 10, Oct. 2018, E-ISSN: 2222-6990 @ 2018 HRMARS

However, Allah S.W.T. also reminds us that He provides sustenance for human little by little according to His wise judgement so that human do not go overboard as His words mentioned in Surah al-Syuraa verse 27.

Hassan (1996), went on further in his analysis and was in the opinion on the argument by Khan (1994) that scarcity of resources is actually a human-made phenomena could not be wholly accepted. Wastage in utilizing it or improper distribution of it is indeed the salt to the wound but not the essence of its scarcity. Assuming that scarcity of resources was a disturbance factor in the 'adequacy' of resources was definitely wrong and unwarranted. It would be quite difficult to interpret this statement but not impossible. Therefore, a better statement would be: limited resources due to human lack of knowledge on the abundant of wealth and sustenance from Allah S.W.T. ${ }^{6}$ This could be translated through the meaning of His words in Surah al-Israa' verse 85 and Surah al-Huud verse 6 (Hassan 1996:582). Allah S.W.T also mentioned in another verse of the Holy Quran in Surah al-Isra' verse 31.

In contrast, different argument was conveyed by Salleh (2011) towards an argument made by Ahmed (2002). Yousri Ahmed (2002) believed that the scarcity of natural resources being the cause of economic problem as well as the basis for the later economic process. Ahmed (2002) also thought of the need to find the best possible method to exploit the economic resources while human's wants are limitless.

Logically speaking however, to maximize the expenditure of natural resources that is considered to be limited also means to quicken its depletion. It would then leave nothing to be inherited by the future generations and most likely would further cause destruction to nature. So, what are the actual contributions of Islamic economics in fostering a more harmonized development as to what Islam supposed to offer? (Salleh 2011). Natural resources in terms of tawheed as well as distribution method promoted by Islam are in fact unlimited. What it meant by limited was the physical aspect of it as well as the quantity (al-Syuraa:27). These natural resources are guaranteed for every human based on what was already set by Allah S.W.T. (Salleh 2003).

\section{Unlimited Wants / Needs}

According to Salvatore (2003), human wants or needs refer to every items, services, and living conditions required by human. These needs are different for every different person at different time, era, and location. While according to Mannan (1984), needs in Islam cover a wider angle. It is not only limited to economics, but also includes social and moral needs. Human will always have the lust of needing their worldly needs. However, Islamic teachings related to consuming and expending would be able to control the lust as mentioned in Surah al-Qalam verse 8.

${ }^{6}$ Indeed, Allah S.W.T. bestowed unlimited blessings upon all His creations for them to live and exist as He wishes with resources from heaven and earth. He decides and provides sustenance for all His creations. 
Human needs according to Islamic perspective are limited within the scope of tawheed, fiqh, and akhlaq or morality. Within this scope of limitations, a Muslim would not be tempted solely by lust. On the other hand, efforts to fulfil the needs would be based upon sane thoughts through their iman towards Allah S.W.T. as stated in the Holy Quran, Surah an-Najm verse 3 (Ahmad et.al., 2011).

If we were to look in the aspects of priority between necessity and needs, Islam actually prioritizes necessity over needs. Fulfilling the basic necessities is important in order to protect the five key elements of living or in the words the Maqasid Syar'iyyah which involves faith, life, intellect, wealth, and heredity ${ }^{7}$. Needs meanwhile are divided into economic, moral, and social needs. Economic needs are determined by satisfaction that is so dependent on a one's lust. However, according to Siddiqi (1992), needs and satisfactions in Islam are determined by the interest of individuals and community. Still, this view was still quite confusing as it was contradicting with Surah al-Takwiir, verse 29. In the aforementioned verse, Allah S.W.T. stated that human could not determine any needs, only what was set by Allah S.W.T.

Therefore, Khan (1995) believed that some needs were prioritized over the other based on how far and important that particular needs can protect the five elements in the Maqasid Syar'iyyah. Hence, the needs promoted in Islam are actually aligned with these patterns. According to Ahmad et.al. (2011), if the basic needs were to be completely fulfilled, an individual is not abstained morally to increase the needs as long as it does not lead to wastage, as mentioned by Allah S.W.T and the hadith of Rasulullah PBUH (al-Isra':27; Hadith narrated by al-Bukhari:6).

Moral needs implies to the needs of knowledge both fardhu ain and fardhu kifayah, preaching, spending wealth, energy, and time in scope of worshipping Allah S.W.T. and performing jihad in spreading Islam. The last needs which is the social needs, is a need in spending or sharing wealth in order to help others or institutions through endowment, charity, will, and many other form of charity with the intentions of gaining Allah's blessing (Ahmad et.al., 2011:44).

In the meantime, according to Salleh (2003:13), the unlimited wants are the manifestations of how evil lust namely ammarah or lawwamah or mulhamah spreads in human's heart and soul. When ammarah, lawwamah and mulhamah are able to be contained, and human can obtain the pure kind of lust such as mutmainnah, radhiyah, mardhiyyah and kamilah, only then human needs can be limited.

\footnotetext{
7 The setting of Sharia law is based on the meaning and objective of Sharia, depending on the reasoning of the problems. The focus lies on the capability of reasoning the laws. The changes of laws in relation to the change of time and place are to guarantee its relevancy to the problems. Every law must be with the objective of protecting the interest of religion, life, intellect, heredity, and wealth.
}

8 Book 8, Vol. 73, No. 6. Please refer to al-Albani (2003). 


\section{Conclusion}

This paper has discussed the views and opinions of Islamic economists on two old issues namely the scarcity of resources as well as the unlimited wants of human, supported by absolute source of the Holy Quran and as-Sunnah. There were two groups of Islamic economists discussing the issues. The first group extracted the conventional economics assumptions and Islamized it. While the second group composed of those who opposed the first group by suggesting that the assumptions must be based on tawheed as its pillar and aligned with tasawwur Islam. A more in-depth and comprehensive discussion have to be done by Islamic economists towards achieving a new resolution on these assumptions so that it would be aligned with the true concept of tawheed and tasawwur Islam, not merely a patch of conventional economics coated with Islamic values.

\section{Acknowledgement}

This research was supported by the Center for Islamic Development Management Studies (ISDEV), Universiti Sains Malaysia, Pulau Pinang, Malaysia. Huge appreciation to Dr. Mohd Zulkifli Muhammad, Dr. Azwan Abdullah, Dr. Nasrul Hisyam Nor Muhamad, and Dr. Mohd Syakir Mohd Rosdi towards the realisation of this article. Dr. Mohd Zulkifli Muhammad and Dr. Azwan Abdullah are senior lecturer of the Faculty of Entrepreneurship and Business, Universiti Malaysia Kelantan. Dr. Nasrul Hisyam Nor Muhamad is a senior lecturer of the Fakulti Tamadun Islam, Universiti Teknologi Malaysia, Skudai, Johor. Dr. Mohd Syakir Mohd Rosdi is a senior lecturer of the Centre for Islamic Development Management Studies (ISDEV), Universiti Sains Malaysia.

\section{Corresponding Author m}

Dr. Mohd Syakir Mohd Rosdi

Senior Lecturer

Center for Islamic Development Management Studies (ISDEV)

11800 Universiti Sains Malaysia,

Penang, Malaysia.

Email: mohdsyakirmohdrosdi@gmail.com/mohdsyakir@usm.my

\section{References}

Ragab, I. (1995). On the Nature and Scope of the Islamization Process: Toward Conceptual Clarification. Intellectual Discourse, 3(2), 113-122.

Abusulayman, A. H. (1973). "The Theory of the Economics of Islam: The Economics and Brotherhood", in Contemporary Aspects of Economics and Social Thinking in Islam, Indiana, USA: MSA of the USA and Canada.

Ahmad, J., Ahmad, S. \& Wahid, H. (2011). Ekonomi Islam: Satu Pendekatan Analisis. Bangi, Selangor: Penerbit Universiti Kebangsaan Malaysia.

Ahmad, K. (1981). Studies in Islamic Economics. Leicester, UK: Islamic Foundation.

Ahmad, K. (1992). "Nature and Significance of Islamic Economics", in Ausaf Ahmad and Kazim Raza Awan (1992). Lectures on Islamic Economics, Proceedings of International Seminar on 'Teaching Islamic Economics for University Teachers', Jeddah, Saudi Arabia: Islamic Research and Training Institute, Islamic Development Bank. 
INTERNATIONAL JOURNAL OF ACADEMIC RESEARCH IN BUSINESS AND SOCIAL SCIENCES

Vol. 8, No. 10, Oct. 2018, E-ISSN: 2222-6990 @ 2018 HRMARS

Ahmad, K. (2004). "Islamizing the Economy: The Pakistan Experience", in Robert M. Hathaway and Wilson Lee, ed., Islamization and the Pakistani Economy, Washington D.C.: Woodrow Wilson International Center for Scholars.

Ahmed, H. (2002). Theoretical Foundations of Islamic Economics, Book of Readings No. 3, Jeddah, Saudi Arabia: Islamic Research and Training Institute, Islamic Development Bank.

Al-Albani, M. N. (2003). Ringkasan Shahih Bukhari. Jakarta: Al-Maktab Al-Islami/Ahmad Semait.

Al-Masri, R. (1998). Ishamat al-Fuqaha Fil Furud al-Asasyyiat Li-Ilm al-lqtesad, Winner of IDB Prize, Lectures Series No. 14, Jeddah, Saudi Arabia: Islamic Research and Training Institute, Islamic Development Bank.

As-Sadr, M. B. (1987). Our Philosophy, trans. Sham S. C. Inati, London, UK: Muhammadi Trust.

Binger, B. R. \& Hoffman, E. (1998). Microeconomics with Calculus. Massachusetts, USA: AddisonWesley.

Case, K. E., Fair, R. C. \& Oster, S. M. (2012). Principles of Economics. Essex, UK: Pearson.

Chapra, M. U. (2001). What is Islamic Economics, Winner of IDB Prize, Lecture Series No. 9, Jeddah, Saudi Arabia: Islamic Research and Training Institute, Islamic Development Bank.

Choudhury, M. A. (1999). Editorial: Islamic Economics and Islamic Political Economy. Managerial Finance, 25(5), 1-3.

Haider Naqvi, S. N. (1983). "Individual Freedom”, Social Welfare and Islamic Economic Order, Pakistan Institute of Development Economics.

Haneef, M. A. (1997). Islam, the Islamic Worldview, and Islamic Economics. IIUM Journal of Economics and Management, 5(1), 39-65.

Hasan, Z. (1996). "Book Review: An Introduction to Islamic Economics by Akram Khan", MPRA Paper, No. 2980, Munich, Germany: University Library of Munich.

Hasan, Z. (1998). Islamization of Knowledge in Economics: Issues and Agenda. IIUM Journal of Economic and Management, 6(2).

Hasanuz Zaman, S. M. (1984). Definition of Islamic Economics. Journal of Research in Islamic Economics, 1(2), 55-60.

Hassan, S. K. (1990). Ekonomi Islam. Bangi, Selangor: Penerbit Universiti Kebangsaan Malaysia.

Hassan, Z. (2011). "Scarcity, Self-interest and Maximization from Islamic Angle", MPRA Paper 31631, Munich, Germany: University Library of Munich.

Kahf, M. (1987). "Islamic Economics: Notes on Definition and Methodology", Proceedings of International Workshop on the Methodology of Islamic Economics, Bayero University, Kano, Nigeria, July.

Khan, M. A. (1994). An Introduction to Islamic Economics. Islamabad, Pakistan: International Institute of Islamic Thoughts and Institute of Policies Studies.

Khan, M. F. (1995). Essays in Islamic Economics. Leicester: The Islamic Foundation.

Khan, M. F. (2002). "Fiqh Foundations of the Theory of Islamic Economics: A Survey of Selected Contemporary Writings on Economics Relevant Subjects of Fiqh", in Habib Ahmed, ed., Theoretical Foundations of Islamic Economics, Book of Readings No. 3, Jeddah, Saudi Arabia: Islamic Research and Training Institute, Islamic Development Bank.

M. Rosdi, M. S. (2014). Tahalluf siasi dalam ekonomi politik Islam: Satu kajian teoretis: Pulau Pinang: Pusat Kajian Pengurusan Pembangunan Islam (ISDEV) Universiti Sains Malaysia. 
INTERNATIONAL JOURNAL OF ACADEMIC RESEARCH IN BUSINESS AND SOCIAL SCIENCES

Vol. 8, No. 10, Oct. 2018, E-ISSN: 2222-6990 @ 2018 HRMARS

Mannan, M. A. (1980). Islamic Economics: Theory and Practice. Delhi, India: Idarah-I Adabiyat-i.

Mannan, M. A. (1984). The Making of an Islamic Economic Society. Cairo, Egypt: International Association of Islamic Banks.

Mannan, M. A. (1989). Ekonomi Islam: Teori dan Praktis, trans. Radiah Abdul Kader, Kuala Lumpur: A. S. Noordeen.

Mohd Rosdi, M. S. \& Mohd Razif, N. A. (2017). Uswah hasanah country of khalifah umar abdul aziz: an islamic political economy research. International Journal of Academic Research in Business and Social Sciences, Vol. 7, No. 6. DOI: 10.6007/IJARBSS/v7-i6/3026. URL: http://dx.doi.org/10.6007/IJARBSS/v7-i6/3026.

Rosdi, M. S.M. \& Mohd Razif, N. A. (2017). Uswah hasanah country of khalifah umar abdul aziz: an islamic political economy research. International Journal of Academic Research in Business and Social Sciences, Vol. 7, No. 6. DOI: 10.6007/IJARBSS/v7-i6/3026. URL: http://dx.doi.org/10.6007/IJARBSS/v7-i6/3026.

Rosdi, M. S. M.(2013). Ekonomi politik Islam: Teori dan falsafah. Kuala Lumpur: Dewan Bahasa dan Pustaka.

Rosdi, M. S.M. (2014a). “Mencari ekonomi holistik: Antara ekonomi Islam dan ekonomi politik Islam”, dlm. Internasional Pembangunan Islam I (KIPI-I). Universitas Jember, Indonesia.

Rosdi, M. S.M. (2014c). Tahaluf siyasi dalam ekonomi politik Islam: Satu kajian teoretis. Thesis was submitted as a requirement for a PhD, Universiti Sains Malaysia.

Rosdi, M. S.M. (2015a). Conceptualization of Islamic Political Economy. American International Journal of Social Science, 4 (4), 71-77.

Rosdi, M. SM.. (2015b). Tahaluf Siyasi Dalam Ekonomi Politik Islam. Ekonomika: Jurnal Paradiama Islam Di Bidang Keuangan, Ekonomi dan Pembangunan, 3 (1), 56-82.

Rosdi, M. S.M. (2015d). Ummah Economic Remedy: Between Islamic Economics and Islamic Political Economy. Journal of Business Management \& Economics, [S.I.], 4 (01), 38-46. DOI: http://dx.doi.org/10.15520/jbme.2016.vol4.iss01.169.pp38-46.

Basmeih, A.M. (1996). Tafsir Pimpinan ar-Rahman kepada Pengertian al-Quran. Kuala Lumpur: Bahagian Hal Ehwal Islam, Jabatan Perdana Menteri.

Nasr, S. V.R. (1986). Whither Islamic Economics?. Islamic Quarterly, 30(4), 211-220.

Salleh, M. S. (2003). 7 Prinsip Pembangunan Berteraskan Islam, Kuala Lumpur: Zebra Editions and Pulau Pinang: Projek Pengurusan Pembangunan Islam (IDMP), Universiti Sains Malaysia.

Salleh, M. S. (2011). "Islamic Economics Revisited: Re-contemplating Unresolved Structure and Assumptions", Proceedings of $8^{\text {th }}$ International Conference on Islamics Economics and Finance, Center for Islamic Economics and Finance, Qatar Faculty of Islamic Studies, Qatar Foundation, Doha, Qatar, Disember.

Salvatore, D. (2003). Microeconomics: Theory and Applications. Oxford, UK: Oxford University Press.

Sardar, Z. (1988). Islamic Futures: The Shape of Ideas to Come. Petaling Jaya, Malaysia: Pelanduk Publications.

Siddiqi, M. N. (1988). "From Contemporary Economics to Islamic Economics", in Abdullah Omar Naseef, ed., Today's Problems, Tomorrow's Solutions, London, UK: Mansell Publishing Ltd.

Siddiqi, M. N. (1989). Muslim Economic Thinking: A Survey of Contemporary Literature, trans. Mohd. Amin Abdullah, Kuala Lumpur: Dewan Bahasa dan Pustaka. 
Siddiqi, M. N. (1992). "Islamic Consumer Behaviour", in Sayyid Tahir, Aidit Ghazali \& Syed Omar Syed Agil, ed., Readings in Microeconomics: An Islamic Perspective, Petaling Jaya, Selangor: Longman Malaysia Sdn. Bhd.

Ahmed, A.R.Y. (2002). "A Methodological Approach to Islamic Economics: Its Philosophy, Theoretical, Construction, and Applicability", in Habib Ahmed, ed., Theoretical Foundations of Islamic Economics, Book of Readings No. 3, Jeddah, Saudi Arabia: Islamic Research and Training Institute, Islamic Development Bank.

Zarqa, M. A. (1992). "Methodology of Islamic Economics", in Ausaf Ahmad and Kazim Raza Awan (1992). Lectures on Islamic Economics, Proceedings of International Seminar on 'Teaching Islamic Economics for University Teachers', Jeddah, Saudi Arabia: Islamic Research and Training Institute, Islamic Development Bank. 